\title{
The Perceptions of EFL Teachers on the Impact of the Usage of Code-Switching in EFL Classroom Management
}

\author{
Ayten Yıltanlılar, Çağda Kıvanç Çağanağa \\ European University of Lefke, Lefka, North Cyprus \\ Email: ayiltanlilar@eul.edu.tr, ckivanc@eul.edu.tr
}

Received 5 November 2015; accepted 20 November 2015; published 26 November 2015

Copyright (C) 2015 by authors and OALib.

This work is licensed under the Creative Commons Attribution International License (CC BY). http://creativecommons.org/licenses/by/4.0/

(c) (†) Open Access

\section{Abstract}

This study aims to investigate university level language teachers' views on how their usage of code switching affects their classroom management in EFL classes. This study is conducted in Turkish setting, which is Cyprus and especially at the European University of Lefke. The participants are selected randomly from the same university and they are the members of the English Preparatory School. They were asked to write five daily reports during one week and they were interviewed for 30 minutes. In order to reach a valid and reliable data, two data collection methods were chosen, which were reflective reports and interview; hence, the nature of the current study was qualitative. In other words, cross-case analysis was used to examine and identify common themes between cases. This study lasted three months; therefore, it was not a longitudinal work, so this research was limited and needed further inquiry. In Cyprus EFL classes, code-switching should be considered and investigated more in classroom management. It is revealed that there is a need to raise EFL teachers' awareness on when and when not to use code-switching. There are certain ways to promote code-switching in EFL classes and there are by providing more seminars, workshops and organizational meetings weekly or monthly.

\section{Keywords}

Code-Switching, Classroom Management, Mother Tongue (L1)

Subject Areas: Education, Linguistics

\section{Introduction}

In a world where everything needs inevitable changes, it is unquestionable for teachers to resist against the power of dynamic phenomena of teaching and learning process. Such an effective force has impacts on many 
fields like science, physique, psychology and education as well as many other which cannot be counted now. In addition to the fields in the previous sentences, teaching practices, techniques, and methods exposed such inevitable change throughout the years can be given as examples, which partly and total change can be observed in teaching methods, techniques and philosophies, learning context and the learners in which teacher and the learners comparing to the past are now more active during this process. When going back in time and reflecting back on those times have passed in the field of language teaching, many observable changes can be seen. Those change movements have started with a single question how and it multiplied with other questions in time. Those questions that were asked and still being asked in the mind of educators and researchers had changed and still were changing the nature of teaching and learning.

The main interest of the language teaching field was to detect more virtuous methods of teaching a foreign language during the twentieth century. However, there was a shift during the twenty-first century different from the previous century. The distinction between these two centuries was conceptual with all-round perspective encompasses both teaching and learning. This multiple perspective had brought a new shape to teaching field in terms of moving away from the conventional way of teaching to more sophisticated trend of teaching. According to Brown, this shift is a fixation of "method" with attention on "pedagogy". These two concepts are broad terms, so if teaching is described in a more simple way planning and managing should come first because planning is seen as a fundamental facet of reaching a successful teaching most of the time [1].

Planning requires a teacher to make decisions regarding objectives, activities, materials, time allocated for teaching and production, grouping students including other aspects of a lesson as discussed in [1].

\section{Literature Review}

“IJUST KNOW I HAVE SOME KIND OF DISABILITY: I CAN'T learn a foreign language no matter how hard I try." "When I'm in my Spanish class I just freeze! I can't think of a thing when my teacher calls on me. My mind goes blank. "I feel like my French teacher is some kind of Martian death ray. I never know when he'll point at me!" "It's about time someone studied why some people can't learn languages" [2].

These statements above may seem familiar to most of the language teachers, which actually tell more about language teachers, with high possibility, may face such responses in language classes. What these reflections of emotions have in common is that language learners are probably having psychological and mental barriers. Learning a language turned into a must in today's world when considering the need of knowing English due to its impact on business, political and educational zones. Taking the role of the target language into consideration, which is English in current case in terms of the purpose of the study, which will be done in a monolingual learning context, has an important effect on the language learners based on the case above, which was one of the representative case of the language learners. I didn’t understand this section. In other words, when considering the learners and the situation that they are in is called a language anxiety, which was an essential block for both the language learners and the teachers in an educational setting. No matter how good the learners are at other domains. It is assumed that the learners' achievement is dependent on how they perceive the new language or the language learning occurs in accordance with whether learners accept that language learning as a natural process of the target language or as a threat that inhibits their learning. In the light of the effect of foreign language on the students brings up a question which needs to be answered. The question is how classroom management is important in language teaching? And what is the relationship between classroom management and language teaching? These questions will be explained in more detailed way in the next page.

\section{The Role of Language Teachers}

Teachers were seen as the sources of the knowledge and an authoritarian figure throughout the years as the teaching methods were teacher-cantered; however, this teacher-centeredness and the source of knowledge have changed over the time as the studies conducted by prominent scholars and educators brought light to these terms and led changes in terms of the perception of these vogue terms. In today's world, these terms and the roles assigned to teachers have changed as a result of the reforms, policies and changes done in language teaching field. Teachers are seen as facilitator, guide, and controller of the class. In other words, many methods and techniques were proposed regarding the role of a language teacher in Littlewood, 1981; Richards and Rodgers, 1986; Tudor, 1993; Harmer, 2001 as cited in [3]. According to Richards and Rodgers (1986) as cited in [3] major teacher roles and responsibilities were identified as follows: 
a) Teachers are supposed to accomplish sorts of duties.

b) Teachers are the controller of the learning environment in which this affects how learning occurs.

c) Teachers have right to make decision on the subject which will be taught.

d) Teachers complete the other side of the coin regarding with interaction pattern between the students and their own [3].

These were not the only characteristics of a language teacher that were identified over the years. What is more, Littlewood, 1981 as cited in [3] developed a concept like "facilitator of learning" (p. 92) in relation to Communicative Language Teaching setting. Similar to Littlewood, Tudor, 1993 as cited in [3] enhanced the concept forward and shifted the focus from teacher-cantered classroom setting to student-centred learning environment in which language learners are expected to be engaged during the learning process, which was defined as an effective language teacher's role in a language class. Here you can see how the roles of the teachers have changed over the decades, so this indicates how important to possess these characteristics and sustain them during the language teaching. However, it may not be enough to gain those skills on their own above because no matter how effective and responsible teacher you are, there are other factors which affects the way you teach, approach, and establish activities in class. All these factors can be said that they are the results of classroom management that teachers try to establish to create a meaningful learning environment. Here comes a crucial question, which has to be answered to bring clarity in terms of the definition of classroom management, which has the relation to this current study.

Classroom management was characterized as teachers no matter if they are novice or experienced use methods and plans to sustain peaceful and noiseless environment. Teachers who are known as constructivist assume that if teachers have adequate classroom management competence, it affects how language learners learn. Therefore, classroom management makes reference to how teachers coordinate students, area, time and resources to hike productive teaching and students learning, Wong \& Wong, 2005 as cited in [4].

As previously indicated, classroom management has an essential link to this current study. When it comes to education, classroom management is regarded as immense concept. If this issue is taken into consideration regarding language learning, there is no doubt that learning exists in the classroom setting. Accordingly, student learning consequences are the results of how classroom management was maintained by the teachers within the learning atmosphere.

Based on these statements above, classroom management is expected to reinforce students' motivation and passion through aiding related pedagogical purposes. Due to these relationships between classroom management, the classroom atmosphere and students learning outcomes, it has direct influence on the students' success. When the term, which is classroom management is evaluated within the scope of this inquiry, narratives that formerly mentioned show how much classroom management and language teaching is connected to each other when considering especially learners achievement in language learning, Reinke, Lewis-Palmer, \& Merrell, (2008) as cited in [4].

If classroom management and the use of the mother tongue are applied into teaching practices, then it is required to come into a distinction between terms that are frequently used in EFL field, which you will also find these key words in this study.

To begin with Mother Tongue (MT), which refers to a "language that one learns first" or "it is identified by others as native speaker of" [5], there is another concept which has importance in this work called Second Language. According to the definition that was taken from (English Dictionary) [6] it is characterized as "a non-native language officially recognized and adopted in a multilingual country as a means of public communication" whereas Foreign Language was described as it is a language, "which is not spoken in the immediate environment of the learner"; therefore, the language learners has limited opportunity to practice the target language in their daily bases communication [7]. Although the use of the mother tongue (L1) had been discussed throughout the years in order to bring richness to this issue, there is still not a conclusive answer. However, according to the study, which was conducted in 2009 by McMillan, Rivers and Cripps as cited in [8] it was revealed that English language teachers have multiple perspectives toward the use of L1 in EFL classes.'

Comparing the past to the present, it can be said that one of the major approach called "monolingual approach" (avoiding students' L1 in classrooms) had impact on the EFL field. Based on this approach, the use of mother tongue was ignored in English language teaching whereas "bilingual approach" (allowing students' L1) altered this view and opened the doors for language teachers to take advantage from the language learners' mother tongue, which was later seen as an effective tool that enhances foreign language learning [8]. The fact that why 
this approach was supported was that it was believed that the more language learners were exposed to the target language the better they are when operating the foreign language, Krashen, 1987, Turnbull, 2001 as cited in [8]. Despite the fact that monolingual approach influenced the classroom practices, its impact is still under the inquiry after bilingual approach bring up. Although the purpose was to diminish the students' inhibiting habits that they try to implement when learning a new language, this did not take too long in the literature with the rise of the new concept called bilingual approach. The term code-switching allows speakers of the shared language and the speakers of other language to change language in accordance with the ease of communication. For this reason, code-switching does not have to be between the common language, it can also occur between "two of more languages" [9]. To put it another way, code-switching was characterized as shift between two or more language in classrooms, which are multi lingual and where English (the medium of education) and grammar rules are taught with an assist of the mother tongue (L1); therefore, mother tongue (native language) plays role as aiding or contingent traits for teachers to explain and make students understand the subject [3]. Based on these statements above, the question to why language teachers need to use code-switching can be enlightened by several reasons.

To begin with, if the use of code-switching is discussed from classroom management perspective, it was claimed that language teachers utilize code-switching not always on purpose but sometimes, they do it without realizing it especially when lecturing; that is, it occurs naturally [10]. One of the reasons as stated in the same source could be the fact that language teachers do not only use code-switching as tools for conversation and boosting students comprehension, but also they take advantage from code-switching in terms of continuance of classroom instruction as language teachers need to manage time, which is one of the main component of classroom management, [10]. Furthermore, some other patterns of code-switching were identified by prominent scholar as following lines. As it was stated above, code-switching or changing languages can be available by language teachers either unconsciously or consciously. When it is consciously done, it was supposed to be done by considering some occasions during language teaching; hence, some of the situations in which both teachers and language learners can use code-switching were provided by [11] as in the following sentences. Not only sentence level is valid when doing codes-switching, but also learners may not understand some words while learning English; therefore, learners automatically turn into Turkish and teachers may also feel in need to use Turkish to make the meaning of the words clear in students' mind. This form of using code-switching is defined as mechanical shifting. It betters the lack of comprehension of unknown and unfamiliar words [11]. Moreover, language teacher can switch codes during any in-class activities either when especially students are in their groups of when they are pairs, (Skiba, 1997, para. 12 as cited in [11]. As has been noted above, language teachers use different techniques and approaches to increase optimal students learning. In terms of this perspective, classroom management is an umbrella term, which includes, anything that teachers tend to do in order to endorse students to reach complete comprehension by organizing instructions, resources; time allocated, spaces for practice and activities as well as grouping students, Wong \& Wong, 1998 as cited in [12]. Likewise, this term is composed of the employment of a management technique, classroom atmosphere, in-class rules, agenda and patterns, pedagogical practices, syllabus and discipline precautions. Classroom management is not only comprised of implementing management procedures; on the other hand, organizing students during teaching-learning process is a crucial trait of providing gainful learning conditions for learners, [12].

This paper seeks to reorient classroom management by using the code switching process of teachers. Given such a mission, using code-switching process for classroom management represents intellectual, pedagogical, and strategic challenges for classrooms. It also emphasizes holistic and learner-centred teaching. It is not surprising then that they [13] support the importance of teacher-initiated and teacher induced code-switching and its relationship to pedagogical focus. This study set out to learn more about the perceptions of the teachers about their use of code-switching while they try to manage their classrooms. This study focuses on the idea that code switching can be a useful tool in assisting classroom management. The literature reviewed has indicated the various positive and facilitating functions of code switching approved by many researchers. The objectives of this research are:

1) To determine the perceptions of teachers on the impact of code-switching in classroom management.

2) To determine the perceptions of teachers on the relationship between code-switching and classroom management.

In the following part how participants selected, where the current study was conducted and how data were gathered will be reviewed. 


\section{Methodology}

Since the nature of study is qualitative, interview as a data collecting tool was used. In addition to interviews, reflective reports were put into practice; hence, the combination of two methods, which increases the validity of the current study, was present. This is defined as triangulation, which means a verifying process includes many aspects and strategies [14]. This part was divided into three main headings namely: Selection of the Participants, Context, and Data collection tool.

\subsection{Selection of the Participants}

One of the participants was a native speaker of English and teaching English unlike the other, who was a nonnative speaker of English, who is working with the same working place and teaching English as a foreign language. Yet, this coincidence, which refers to teachers were being categorized as native and non-native speakers of English, does not change the nature of the study. Likewise their language proficiency, their year of experience was totally different from each other. Although the native language teacher's work experience is almost six years, the non-native English language teacher's working experience was three years. Finally, the participants' age range is 24 and 28 and two of the participants are continuing their career in the same work place, which is The European University's Preparatory School.

Using the qualitative constructivist theoretical perspective [15] this study aimed to examine "what are the participants” reported perceptions, truths, explanations, beliefs, and worldview' [15] about their classroom management approach. More specifically, this study focused on how two preparatory school teachers reflected on their classroom management regarding code switching. The participants, Barbara and Jennifer, were selected through purposeful sampling [15] to show the reflections of two exemplary English teachers. They were selected because their students and colleagues have described them as being effective English teachers.

Why we examine teachers' reflections on the impact of code switching in classroom management?

Reflection is a crucial component of reviewing one's practice and "taking time to step back and ponder the meaning of what has happened, the impact of it and the direction one is taking” [16]. As a systematic and purposeful methodology for examining one's own practice, reflection makes it possible to understand and resolve conflicting situations and expectations through inquiry [17] [18].

While examining one's learning and teaching process, we can also begin to make his/her understandings and beliefs explicit. Teachers need to focus on their understandings and beliefs about the importance of using codeswitching to manage their classrooms well. Research has emphasized the link between code switching and learning. The anxiety free classroom atmosphere encourages them to participate more actively in the classroom activities. Therefore, learning success requires successful provision of comprehensible input to ensure learners understand the intended content, covering new concepts, skills and vocabulary which would consequently translated into successful execution of tasks [19]-[21].

\subsection{Context}

This current research is conducted in a Turkish setting, which is Cyprus and especially as previously mentioned in the European University of Lefke (EUL). Two of the participants are members of the Preparatory School of EUL, which English is the medium of Instruction. The reason to why the participants were selected from the same work place is that since the research conductor is working in the same place, it was believed that this can bring an advantage in terms of the time and practicality.

\subsection{Data Collection Tool}

The participants first were given a reflective report, which they were required to write down five reflective diaries as daily bases at full length one week based on their sincere and honest experiences on the use of codeswitching in their language classes in terms of classroom management. After one week, they were interviewed for 30 minutes regarding how code-switching influenced their classroom management. There were nearly eight questions in the interview and some sub questions were asked according to the conversation. The participants were informed about the purpose of the interview and their consents were gained before the interview was conducted. Since gaining more valid and reliable data was one of the main purposes of this study, two data collection tools were used; therefore, the nature of the current study was qualitative. In other words, as it was aimed to 
provide more comprehensive and conclusive interpretation of the collected data rather than reaching statistical findings, this study remains in the qualitative level. As final anecdote, this study took three months in total; hence, it was not a longitudinal study.

All these procedures were followed because of the purposes of this study, which is to find out answers to the questions as follow:

\subsection{Research Questions}

1) Is there a significant difference between using TL and MT in relation to classroom management?

2) What is the impact of teachers' using code switching on their classroom management?

3) What is the perception of EFL teachers' usage of code switching and its relation to the classroom management

\subsection{Findings}

In this section, the findings will be analysed about teachers' perception on how, when and to what extent they utilize code-switching and how these affect classroom management in their EFL classes. This fragment is arranged in accordance with the research questions route this study: a) Is there a significant difference between using TL and MT in relation to classroom management? b) What is the impact of teachers' using code switching on their classroom management? and c) What is the perception of EFL teachers' usage of code switching and its relation to the classroom management? Under the light of these questions, the findings will be discussed under these categories with assist of some major interview questions as below:

\subsubsection{Functions of Code Switching in the Classroom}

Code switching is used by the participants to reduce opportunities for students to stop their disruptive behaviours.

"How often do you use Code Switching in your EFL classrooms as a management strategy?

- In which occasions (when a problem arises, to guide, while teaching, for clarification, checking comprehension) do you prefer using code-switching?”

Both of the participants were asked the question as above and they mentioned that the use of code-switching is very important in classroom management. Statements taken from both interviews and reflective reports bring clarity as in the following lines of both participants:

"There can be some disruptive behaviour arouses, I prefer using Code-switching as a classroom management tool". "I warn them by using Turkish to stop them doing their unwanted behaviours."(Barbara, Interview).

Similar to her statements, what she said during the interview matched what she did in her EFL class, which can be exemplified as

"The lesson was about solving the workbook answers so while we were doing this part, two students started to use their mobile phones so I went next to them to warn them and when I walked next to other students, they started to use their mobile phones again because they were playing football together so I stopped the lesson and I used Turkish" (Barbara, Reflective Report).

Likewise, the findings revealed that the other participant called Jennifer uses code-switching as means of diminishing unwanted behaviours in her class.

"When I am angry I turn into Turkish so that I can make them understand. First what I do usually is I use my actions like my face but when I am angry I am like "yeteeer! (enoughhh)!" Be quite "yetergonuştunuz!, (that's enough you talked!)" I am like quite please quite please. And they don't understand, they don't take me serious, when I use just one word like "yeteeerrr!" and end up chik, zip, there was a change in their behaviour." (Jennifer, Interview), which she elaborated her comments in her reflective reports just like she did in interview.

"The students really annoyed me today; I asked them to work in groups to discuss the topic that was given to the students. Then they started talking in Turkish. It would have been alright as long as they are talking 
in English; therefore, I warned them a couple of times but nobody listened to me, so I warned them in Turkish and everybody went silent and continued to talk in English." (Jennifer, Reflective Report).

In terms of decreasing students' misbehaviours and taking disruptive behaviour students under control can be done with the help of using code-switching from English to Turkish, which is the mother tongue of the learners according to both participants view. In a study conducted by [22], it was found relation between using codeswitch as means of classroom management in order to officiate students either distruptive or thos who come late and even to grab students' attention. However, code-switching was not only utilized to lessen misbehaviors but it was also implemented to enhance students' foreign language intake. On the one hand Jennifer found codeswitching beneficial interms of clarifying ambiguous vocabulary; on the other hand, Barbra regarded it effective especially both when making words more understandable together with explaining sentences by dividing them into small units. For example Jennifer expressed her opinions as follows:

"For example, when my students don't understand and answer a question I either use actions or turn around and say one key word in their mother language for them to understand." "I am usually a person who is very active and if I use my actions and stuff and they understand but there is something that you can't use with their actions for; for example, the word "sensible" if I end up being like you know, if I put my shoulders up, stand up straight and walk in the classroom, they think the word "confident" where sensible is something totally different from confident so they misunderstand that so I have to show either pictures or code swithch from English into Turkish." "Turkish is not used as checking comprehension, especially for reading passage, when you translate it into Turkish it is not Turkish it is something else. If it is one word it is alright, when it's the whole sentence, you cant do that because it really confuses them more. I think in vocabulary, Turkish should be used, just one word like.”(Jennifer, Interview).

Whereas Barbara thought different and benefitted from using code-switching while teaching in a different way such as:

"When you say as a tool, we use English as a tool all the time". "Sometimes it is a kind of tool to help us to make the meaning clear, to help students to understand what we explain but it is a kind of reminder sometimes, it depends." "I use Turkish for especially difficult vocabulary actually for to make the meaning clear, it is like this way in my class". "I explain the general meaning not the Turkish, instead of giving the Turkish meaning, I try to explain the general meaning or I can give example by using them in the class to show or maybe if I want to use Turkish I separate the sentence in two parts and then I explain them in Turkish "maybe" (Barbra, Interview).

Although both of the participants use code-switching as an aid to improve students meaningful language input, both of them have slight difference interms of how they use code-switching within teaching context. What they do can be expalined further with their sincere experiences that they shared in their reflective reports, which they wrote for five days as daily bases. As noted above, Barbra preferred to use codes interchangeable in order to either explain difficult vocabulary or sentence and grammar structures that students can not easily get the meaning. According to her:

"While I was explaining the usage of modals, I used Turkish for the key words. For instance; May/Might for possibility (olasılık), can't for impossible things (imkansız şeylerde) and must (we have an evidence/ kanit) and then I ask them why do we use them and they said their answers in Turkish or English.” (Barbra, Reflective Report).

When it comes to Jennifer, she agrees with the idea of taking advantage from students' mother tongue especially not explaining the sentence structure but esplaining unclear words in the context although she used her actions a lot, she also added that she ended up using Turkish because she sees blank faces and not clear minds infront of her while transferring meanings. For instance she told as:

"Today I used code-switching in only one particular point. The book gave a variety of adjectives. I always like to act out the words or show flashcards but there was one word that could not be acted out or shown as a picture and that word was 'sensible'. I ended up speaking L1 in the class as I couldn't act or give any pictures to support the definition of the word. Although I used sentences to describe the word, students still had difficulty understanding the meaning, so my last choice was to use code-switching. It did really help and students questioned to why I hadn’t used Turkish before...” (Jennifer, Reflective Report). 
In the same vein, some studies have already emphasized how code-switching had impact on classroom management. Since students, who are learning English as a foreign language may feel the lack of vocabulary because of their limited vocabulary background; hence, learners lean to switch codes with the help of their rhetorical capacity they carry from their mother tongue rather than their foreign language, which is English. For this reason, like teachers do, learners do code-switch in order to overcome language obstacles to reach comprehensible sense [23]. What is meant by classroom amangement has already explained in the previous chanpters; however, it is essential to clarify it. This term can includes major features like, grouping students, using materials fits to the theme, establishing activities, utilizing clear and understanable instructions while teaching with specified techniques and methods within the allocated time. Thus, code-switching used as a strategic tool to smoothen all these phases. Nonethless, how code-switch is used differ from teachers to teachers, context to context and students to students. According to the data analysis, findings have shown that both of the English langauge teachers favored adopting code-switching in their EFL classes for slightly different purposes.Apart from these functions in the previous lines, the findings of this study have shown that both of the language teachers are aware of how students' mode during teaching vary and both of the language teachers tried to change the situation in a positive way by using code-switching or students' mother tongue in a humorous way. The following lines have shared with the intention to give you more insight about how two of the participants could be able to gain their language learners especially when they got lost in the class as the line indicate below: Barbra said that she uses English all the time but she uses humour with Turkish language like,

"Childrenlarim, kind of words, it's cok aylp, kind of words, some Turkish some English, combining parts of the word from English to Turkish like "Children"-"larım”. To make it funny," (Barbra, Interview).

This brings up the concept of humor usage in the language class to make a fun and positive classroom atmosphere, which shows the importance in terms of the classroom management by using small chunks of words from Turkish with English words to bring humor, which is believed that this can help students to feel lees anxiety during the language learning. What Barbra did can be elloborated more with Jennifer's case as suggested in the following lines:

"There are advantages of the mother tongue, I feel like psychologist, I am always trying to motivate them and that's when I use Turkish as well, the mother tongue, like okay hade guys, hade arkadaşlar (come on guys), yapabileceksiniz (you can do it), come on guys. When I say come on I feel that they don't really get the meaning, but when I say it in Turkish they say like look the teacher doesn't speak Turkish a lot but when she does she is doing for a reason. I am not saying that Turkish is irrelevant, it supports, like motivation wise, it makes them more to learn." (Jennifer, Interview).

She uses Turkish for a reason, for a purpose,which shows us she make is consciously like Barbra made conscious decision by considering students' needs in those specific cases. Based on these statements it can be interpreted as both of the language teachers used students' mother tongue to bring humour into their lessons. The difference was Jennifer gained opportunities of using code-switching in her class wisely in order to make her learners feel less anxiety. Obviously, this can be an evidence that she activate her emphatetic skill to understand the learners in any case, which requires open-heartedness and open-mindness just like psychologist are, which she formerly referred. If the some functions of code-swithcing are considered, the third aspect can be the fact that language learners come across with challenges that they experience during learning process. One of the challenges can possible be language anxiety due to language learners less competence on the new language, which is English as a foreing language in our cases. Since psychological barrier like negative feelings and opinions toward the new language negtively affect gaining meaningful input in an understandable way, the learners feel under stress; thus, the more they are flexible during learning English, the easier they can concentrate on the subject and take part in activities in a more successful way. Consequently, emotional support allows language learners be much more flexible to acquire English, by regarding learning a new language as alternative to their mother tongue [23]. After all, it can not be ignored for what reasons language teachers prefer to use code-swithcig during language teaching; thus, they were asked to share their views on to what extent codeswithcing should be used as they have already experienced the usage of switching codes. The necessary information will be given in the next part.

\subsubsection{Teachers' Perception on When or to What Extent Code-Switching Should Be Used}

It was seen that language teachers either who totally support Only English or English with assistance of mother 
tongue view did not reject the fact that they implement code-switching method during English language teaching. In addition to this assumption, the question: "How much important that we model language use in the classroom?" was asked to the interviewees and both of the learners admitted that they switch codes from English to Turkish when necessary. How they expressed their opinions will be provided you from their interview session as the following lines:

"I use Code-switching between Turkish and English; therefore, I can't say that I don't use code-switching at all. I use it sometimes if I feel the need of using it when it is necessary. Although I use Turkish at some pints, this doesn't mean that I balance the two codes in mu language class. I favour English rather that balancing English and Turkish by suggesting that if Turkish is used all the time, how the students will learn to speak English by considering international students as well. I want them to be exposed to the use of English.” (Barbra, Interview).

Equally, Jennifer drew a clear picture about to what extent she changed codes from English to Turkish as below:

"I always use English but students always use Turkish and for example I tell them use English, use English please, so I pressurize them to speak in English.” And when I realize that they are using or switching into Turkish I ignore them. This time they understand that they have to speak in English.” (Barbra, Interview).

Under these circumstances, it can be implied as although both of English language teachers admitted that they take advantage from students' mother tongue while teaching English; nonetheless, they clarified that this should not be understood as they favour Turkish more than English as both of them are aware of the more students are exposed the authentic usage of the foreign language the better they are in operating the target language. Last but not the least aspect, which is the most significant part of this study, was about how using code-switching affect classroom management as it was explained in the final part.

\subsubsection{How Does Code-Switch Affect Classroom Management?}

The participants suggested similar views on code-switching technique and both of them stated that they used code-switching not as a methodological or sometimes partly instructional mean to teach English rather they benefited from code-switching as a behavioural aspect. To put it more simply, what they do is to diminish disruptive behaviours; therefore, as they seek change in students' behaviour, both of them wanted these type of learners to understand that they did something wrong and it should be modified or totally changed. That is why, both language teachers used Turkish to make sure that the learners get the meaning from teachers' perception and they become aware of their inhibiting attitudes in class. Thus, they used code-switching as problem solving tool related with whole classroom management aspect. Here what they depicted in both their Interview and Reflective Reports:

"The students really annoyed me today; I asked them to work in groups to discuss the topic that was given to the students. Then they started talking in Turkish. It would have been alright as long as they are talking in English; therefore, I warned them a couple of times but nobody listened to me, so I warned them in Turkish and everybody went silent and continued to talk in English." (Jennifer, Reflective Report).

In the same way, Barbra said as below:

"There can be some disruptive behaviours arouse, I prefer using Code-switching a classroom management tools" "I warn them by using Turkish to stop them doing their unwantedbehaviours." (Barbra, Interview).

Correspondingly,

"When I am angry I turn into Turkish so that to make them understand. First what I do usually is I use my actions like my face but when I am angry I am like changing language from English to Turkish to make them realize something is wrong with their behaviours" (Jennifer, Interview).

Here as it can be understood, both of the teachers wanted a change in students' behaviour so that the whole classroom atmosphere cannot be affected negatively, which can be sustained only an effective classroom management policy in which all the learners have equal rights. 


\section{Discussion}

The study has shown that although there were slight differences between both participants about the usage of code-switching in EFL classes, they agreed on that they both found in a position in which they had to implement it either to solve in class problems that resulted from students disruptive behaviours or clarify ambiguous points that make learners feel distant toward English language as they face with challenges. What was mainly gained from this work can be put into words in more conceptual way. That is to say, both of the participants accepted that code-switching can help learners to reach more overt meanings; therefore, it was defined as meaning clarifying factor along with reminder feature when teaching difficult vocabulary. Moreover, code-switching was regarded as fun element that brings humorous into EFL classes that contribute to teaching learning process by helping teachers seen as friendly beings like making subject more entertaining to learn. Due to these reasons, teachers' code-switching can be seen as motivational and encourager aid. Likewise Ferguson, 2003 as cited in [24] propesed three inclusive classes as thereafter:

1) CS helps learners to comprehend the topic related to the curriculum frame.

2) CS as classroom management approach mottivates, restraines and encourages learners to show alteration in their attitudes.

3) CS used to establish friendly relationships by providing positive climate with the help of emotional aspect in EFL classes.

All in all, the results have in common and similarities between previously conducted studies in the past and recent time period.

\section{Conclusion}

To conclude, the discussion was over how much code-switching had impact on classroom management in EFL classes. Some of the essential questions were tried to be answered to give you more deep understanding on the current issue while many questions were still waiting to be remarked. Furthermore, this study was conducted with intention to bring light on the language teachers about to what extend they could benefit from codeswitching when teaching English language. Finally, findings had revealed that both Jennifer and Barbra were aware of CS bringing advantages to their EFL classes; on the other hand, it could be disadvantageous, which was admitted by the both of them. Their beliefs can enhance and support the possible positive views about the usage of CS for further studies, which can be an inspirational point for other researchers. As a result of findings, it can be seen in a more clear perspective that classroom management can be shaped with the help of different techniques. Therefore, CS which is remained as one of the effective techniques among others has already known.

\section{Limitations of the Study and Recommendations}

As previously stated before, it is crucial to gain insight about the parameters that can change the route for teachers to reach influential classroom management, in order to sustain a successful classroom management. The aim is to provide educators the adequate knowledge and skills needed to establish impressive classroom management in especially EFL classes. A limitation of the current study was the number of participants. The size, convenience, and homogeneity of the sample limit the generalizability of this study. Since the study reviews two preparatory school teachers at the European University of Lefke, who are both experienced teachers, it is essential to go further in order to provide more extensive inquiry how CS has impact on classroom management and what kinds of competencies and strategies they need to have in EFL classes. Based on the results of this study, CS is essential for EFL classes. This study will also shed light on both teachers and administrative engaging individuals and organizational activities. In addition, students can improve their English proficiency by using codeswitching unconsciously differently from teachers' conscious usage of code-switching.

\section{References}

[1] Richards, W. (2011) Classroom Management. ELT Journal, 69, 205-208.

[2] Elaine, K. and Horwitz, M.B. (1986) The Modern Language Journal. In: Foreign Language Classroom Anxiety, Blackwell Publishing, Oxford, 70, 125-132.

[3] Chowdhury, N. (2012) Classroom Code Switching of English Language. Bangladesh Journals Online, 7, 40-61.

[4] Fan, C.-L.H.-C. (2014) Perceived Classroom Management and Student Learning Motivation in Social Studies of Tai- 
wan Junior High School Students. European Journal of Research in Social Sciences, 2, 40-51.

[5] Charlene Rivera, T.R. (2014) Mother Tongue-Bilingual Education. IBIS Concept Paper.

[6] English Dictionary (2014) Retrieved from Collins Dictionary. http://www.collinsdictionary.com/dictionary/english/second-language

[7] Ringbom, H. (1980) Institution of Education Science. Vocabulary Frequencies in Advanced Learner English. In: Granger, S., Ed., Learner English on Computer Longman, London, 41-52.

[8] Tsukamoto, M. (2011) Students’ Perception of Teachers’ Language Use in an EFL Classroom.

[9] Macaro, E. (2006) Code Switching in the L2 Classroom. In: Llurda, E., Ed., Non-Native Language Teachers Perceptions, Challenges and Contributions to Profession, Springer Science + Business Media, LLC, Marid.

[10] Modupeola, O.R. (2013) Code-Switching as a Teaching Strategy: Implication for English Language Teaching and Learning in a Multilingual Society. IOSR Journal of Humanities and Social Science (IOSR-JHSS), 14, 92-94.

[11] Kasperczyk, L.-A. (2005) Implementing Code-Switching in the Classroom.

[12] Deaton, C. (2013) Teachers’ Reflections on Effectively Managing Their Classroom: A Discussion of How Two Experienced Science Teachers Examined Their Classroom Management Practices. Reflective Practice: International and Multidisciplinary Perspectives, 14, 240-257.

[13] Üstünel, E. and Seedhouse, P. (2005) Why That, in That Language, Right Now? Code-Switching and Pedagogical Focus. International Journal of Applied Linguistics, 15, 302-325. http://dx.doi.org/10.1111/j.1473-4192.2005.00093.X

[14] Rahman, S.Y. (2012) “Triangulation” Research Method as the Tool of Social. BUP Journal, 1, 154-163.

[15] Patton, M. (2002) Qualitative Research and Evaluation Methods. 3rd Edition, Sage, London.

[16] Higgins, D. (2011) Why Reflect? Recognising the Link between Learning and Reflection. Reflective Practice, 12, 583584. http://dx.doi.org/10.1080/14623943.2011.606693

[17] Richardson, V. (1994) Conducting Research on Practice. Educational Researcher, 23, 5-10. http://dx.doi.org/10.3102/0013189X023005005

[18] Weiss, E.M. and Weiss, S.G. (2001) Beginning Teacher İnduction (Report No. EDO-SP-1999-3). Office of Educational Research and Improvement. (ERIC Document Reproduction Service No. ED436487), Washington DC.

[19] Schweers, C. (1999) Using L1 in the L2 Classroom. English Teaching Forum, 37, 6-13.

[20] Chi, W.C. (2000) The Importance of Bilingual Teachers to Chinese-Oriented AMEP Learners. The AMEP Conference 2000. http://www.nceltr.mq.edu.au/conference2000

[21] Tang, J. (2002) Using 11 in the English Classroom. English Teaching Forum, 40, 36-43. http://exchanges.state.gov.forum/vols/vol40/no1/p36.pdf

[22] Yao, M. (2011) On Attitudes to Teachers' Code-switching in EFL Classes. World Journal of English Language, 1, 1928. http://dx.doi.org/10.5430/wjel.v1n1p19

[23] Çavuşoğlu, H.B. (2013) Reasons for the Teachers’ Uses of Code-Switching in. Hasan Ali Yücel Eğitim Fakültesi Dergisi, 20, 69-82.

[24] Thompson, G.L. (2006) Teacher and Student First Language and Target Language Use in the Foreign Language Classroom: A Qualitative and Quantitative Study of Language Choice. Dissertation Abstracts International, A: The Humanities and Social Sciences, 67. 